\title{
THE IMPACT OF NEW TRADE AGENDA TO MACROECONOMIC PERFORMANCE OF INDONESIA AND JAPAN IN SHORT AND LONG TERM
}

\author{
Amalia Adininggar Widyasanti ${ }^{1}$
}

\begin{abstract}
The swings of global trade in recent decades have been resulted from the global economic crisis and unfavorable condition of global situation. Deterioration of private demand -- as a result of economic crisis and increase of unemployment - has been the main reason of worsening global trade. This condition has, of course, affected economic performance of countries through trade channels. Furthermore, the recent trade agenda following to Trump administration has created another uncertainty to the world economy. This paper studies the impact of new trade agenda, which is represented by Trump's plan on trade policy, to the world economy as well as to Indonesian and Japanese economy in particular. The analysis is based on computable general equilibrium of GTAP model version 6, with two scenarios: (i) Trump Trade Agenda when implementing 45 and 35 percent tariff to China and Mexico; (ii) Trade Hit List when imposing tariff to the 16 countries in the trade hit list. Impacts of both scenarios are examined in short run and long run. The results suggest that both scenarios in the short run will not create any significant effect to global economy as whole nor to Indonesian and Japan in particular. However, their impacts to the global economy, Indonesia, and Japan will be substantial in the long run. Therefore, Indonesia and Japan in particular should concern on providing sound economic policies to reduce the risk of new trade agenda to these economies in the long run. Some policy recommendation provided in this paper are: (i) Japan should focus on improving technological innovation to realize the implementation of society 5.0 and industry 4.0 as scheduled; (ii) Indonesia should facilitate more investment to its economy and provide more government investment to induce accumulation of capital stock in the future. Furthermore, efficiencies and technological adoption should also be main concern of the Indonesian government to induce productivity of the economy and help mitigate the global risks in the long run.
\end{abstract}

Keywords: trade, macroeconomy, Indonesia, Japan

JEL Classification Code: F17, F47, F62

1 Amalia Adininggar Widyasanti is a PhD graduate from Department of Economics, University of Melbourne, Australia. She is currently a Director of Macroeconomic Planning and Statistic Analysis at Ministry of National Development Planning (BAPPENAS)

Contact Address:

Email: winny@bappenas.go.id; awidyasanti@gmail.com

Phone: +62-813-19353077

The author appreciates inputs, suggestion, and discussion towards this paper from Prof. Nakamura and Prof. Kawasaki (Graduate Research Institute for Policy Studies, Tokyo, Japan) and Prof. Kuwahara (Cabinet Office, Japan) during her research visit on $1-8$ July, 2017 in Tokyo, Japan.

Disclaimer: Views and opinions expressed in this paper are the author's own and not reflected or represented the institution policy and decision. 


\section{INTRODUCTION}

The growth of world trade in recent decades has been quite volatile. The upswings and downswings of global trade growth were resulted from changes of global political and economic situation. For example, the global financial crisis happened in the mid 2008-2009 has destroyed flows of global trade, as the global demand was deteriorated. Furthermore, the election of Donald Trump as the President of the United States has raised a risk to the global economy, in particular to emerging economies which are considerably main suppliers to the US market.

\subsection{The Global Economic Crisis}

The history tells us that the crisis hit the global economy in a cyclical pattern, which was about once in each 8-10 years. The global crisis was often followed by the decline in global trade, as depicted in Figure 1. The dynamics of global trade growth has been moving in the same direction as the global economic growth. In 1988, a decline in the global trade was due to the Iraq-Iran war and the fell of oil prices. The global recession came swiftly after the Black Monday of October 1987, resulting from a stock collapse (e.g. Dow Jones Industrial Average fall by $22.6 \%$ ), which then created a global trade downturn in early 1990s. The continuation of the global recession was largely attributable to declining growth rates in Europe (excluding the U.K.) and Japan. The UK recession of 1991-92 was caused by high interest rates, falling housing prices and the end of the 'Lawson boom'. High interest rates of the late 1980s or early 1990s caused a fall in house prices, leading to a negative wealth effect, because many homeowners ended up with negative equity and bank losses also increased.

Furthermore, the U.S. economy was slowing down and dipped into recession in 1991. The federal budget deficit increased) as the economy contracted and unemployment increased (by 1.8 million workers). The recession ended in March 1991, but the economy was experiencing a jobless recovery, where unemployment was stagnant.

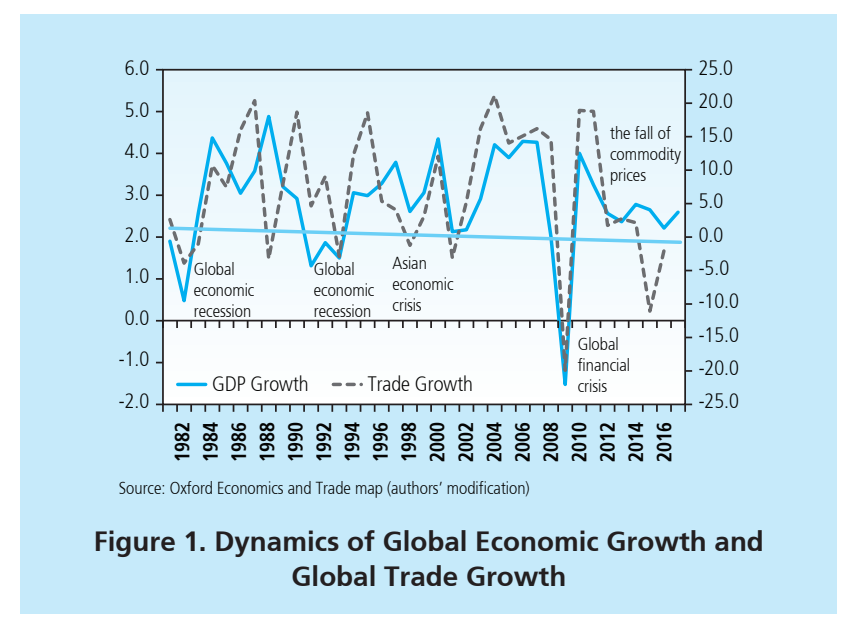


In 1997-1998, Asian economies were unfortunately hit by a crisis. The crisis was started in Thailand with the collapse of the Thai baht after the Thai government was forced to float the baht due to lack of foreign currency to support its currency peg to the U.S. dollar. At the time, Thailand had acquired a burden of foreign debt that made the country effectively bankrupt even before the collapse of its currency. The crisis then spread to most of Southeast Asia and Japan due to slumping currencies. Indonesia, South Korea, and Thailand were the countries most affected by the crisis.

The financial crisis of 2007-2008, also known as the global financial crisis and the 2008 financial crisis, is considered by many economists to have been the worst financial crisis since the Great Depression of the 1930s. It began in 2007 with a crisis in the subprime mortgage market in the US, and developed into a full-blown international banking crisis with the collapse of the investment bank Lehman Brothers on September 15, 2008. Excessive risk-taking by banks such as Lehman Brothers helped to magnify the financial impact globally. Massive bail-outs of financial institutions and other palliative monetary and fiscal policies were employed to prevent a possible collapse of the world financial system. It was then followed by the European debt crisis, a crisis in the banking system of the European countries using the euro. Europeans trust in government has dramatically declined since the onset of the crisis-particularly in the nations that have been hardest-hit. In Southern Europe, the crisis and responses to it have eroded trust in government. This condition hit the global demand, and the global trade was slumped. A remarkable feature of the recent crisis is the collapse in international trade. This collapse is global in nature (WTO 2009), and dramatic in magnitude. Levchenko et.al (2009) found that imports and exports in the US dropped relative to the level of overall economic activity if international trade flows are systematically biased towards sectors in which domestic absorption fell the most.

In 2015-2016, the weak trade growth of just 1.3\% was partly due to cyclical factors as economic activity slowed across the board, but it also reflected deeper structural changes in the relationship between trade and economic output. The most trade-intensive components of global demand were particularly weak last year as investment spending slumped in the United States and as China continued to rebalance its economy away from investment and toward consumption, dampening import demand (WTO, 2017). The WTO is forecasting that global trade will expand by $2.4 \%$ in 2017 ; however, as deep uncertainty about near-term economic and policy developments raise the forecast risk, this figure is placed within a range of $1.8 \%$ to $3.6 \%$. In 2018, the WTO is forecasting trade growth between $2.1 \%$ and $4 \%$.

\subsection{Trade Performance of Asian Countries}

There are various achievement in trade performance of Asian countries. China's trade has been surpassing the US trade within the recent years. Its share of exports in goods and services to the world achieved more than 10 percent in 2012, while the US share to the world export tended 
to decline. A remarkable achievement of China's trade was to increase its share of goods and services export from 0.6 percent in 1980 to 10 percent within just 32 years.

On the contrary, Japan's share to the world's goods and services exports has been declining. Its share in 2016 was only 4.2 percent, decreasing from about 7 percent in 1984. Meanwhile, the share of Indonesia to the global trade was flat, which is around 1 percent of the total world exports, and it seems that Vietnam will overtake Indonesia's position in the global market soonest.

Another phenomena to point out is that Indonesia's and Japan's export growth was moving in the same direction. Both countries were experiencing a negative growth of export during the recent global economic crisis in 2008-2009. In 2010, exports of both countries recovered very fast, as it was helped by global demand recovery. However, in 2016, even though countries' exports were recovering, Japan seems to recover much faster than Indonesia does.

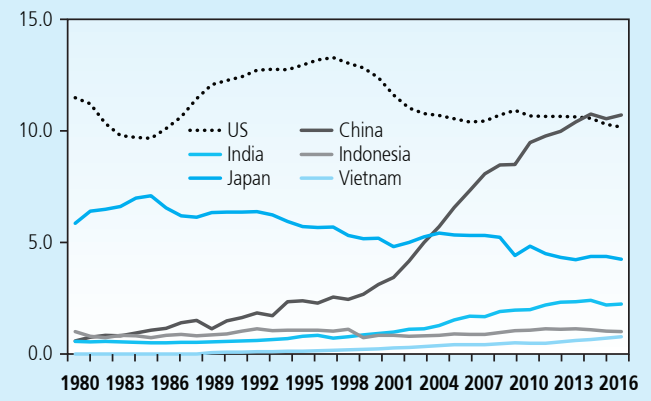

Figure 2.

Export Value of Some Asian Countries

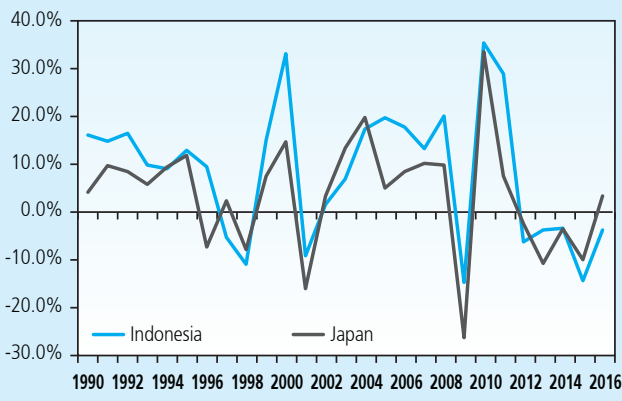

Figure 3.

Export Growth of Indonesia and Japan

Indonesia and Japan has a close trade relationship. Japan is Indonesia's main export destination, where 11.1 percent of Indonesian exports were directed to Japan. On the other hand, Japan is also Indonesia's main import sourcing, as Japanese products share about 10 percent of Indonesian imports. Indonesia and Japan trade are complementary each other, as both countries have different comparative advantage each other.

Indonesia is the main world supplier for Palm Oil, Coal, and Jewelries. On the other hand, Japan is the main world supplier for Machineries, motor cars, as well as parts and accessories of vehicles. Japan main export markets are US, China, and Korea; while Indonesian main export markets are China, US, and Japan. 


\begin{tabular}{|c|c|c|c|c|c|}
\hline \multicolumn{6}{|c|}{$\begin{array}{c}\text { Table } 1 . \\
\text { Top Export Products of Indonesia and Japan to the World Market }\end{array}$} \\
\hline \multirow{6}{*}{ Indonesia } & $\begin{array}{c}\text { Top } 5 \text { Export Products to the } \\
\text { world }\end{array}$ & $\begin{array}{c}\text { Value of } \\
\text { Exports, USD } \\
\text { million (2016) }\end{array}$ & $\begin{array}{l}\text { Share in World } \\
\text { Exports }\end{array}$ & $\begin{array}{l}\text { Ranking in the } \\
\text { world export }\end{array}$ & $\begin{array}{l}\text { Main Export } \\
\text { Markets }\end{array}$ \\
\hline & Palm Oil and its fractions & 14.4 & $51.7 \%$ & 1 & \multirow{5}{*}{$\begin{array}{l}\text { China(11.6\%) } \\
\text { US }(11.2 \%) \\
\text { Japan }(11.1 \%) \\
\text { Singapore }(7.8 \% \\
\text { India(7\%) }\end{array}$} \\
\hline & Coal & 12.9 & $17.3 \%$ & 2 & \\
\hline & Petroleum gas & 7.0 & $4.0 \%$ & 9 & \\
\hline & Petroleum Oil & 5.2 & $0.8 \%$ & 24 & \\
\hline & Jewellery & 4.1 & $4.3 \%$ & 9 & \\
\hline \multirow[t]{5}{*}{ Japan } & Motor cars & 91.9 & $13.2 \%$ & 2 & \multirow{5}{*}{$\begin{array}{l}\text { US(20.2\%) } \\
\text { China(17.6\%) } \\
\text { Korea(7.2\%) } \\
\text { Taipei(6.1\%) } \\
\text { Hongkong(5.2\%) }\end{array}$} \\
\hline & Parts and accessories & 31.7 & $8.8 \%$ & 3 & \\
\hline & Electronics & 24.1 & $4.5 \%$ & 8 & \\
\hline & Machines & 17.8 & $30.8 \%$ & 1 & \\
\hline & Ships and boats & 12.2 & $16.4 \%$ & 3 & \\
\hline
\end{tabular}

Indonesia runs a trade surplus with Japan, because Indonesia supplies a lot of raw materials to Japan for its industrial process. The top import products of Japan supplied by Indonesia are petroleum gas, coal, copper, oil, and wires. On the other hand, Indonesia imports industrial products from Japan, such as: parts and accessories, iron products and steels, machineries, motor cars, and piston engines.

\begin{tabular}{|c|c|c|c|}
\hline \multicolumn{4}{|c|}{$\begin{array}{l}\text { Table } 2 . \\
\text { Bilateral Imports of Indonesia and Japan }\end{array}$} \\
\hline \multicolumn{4}{|c|}{ IMPORTS } \\
\hline \multicolumn{2}{|c|}{ Indonesia from Japan } & \multicolumn{2}{|c|}{ Japan from Indonesia } \\
\hline $\begin{array}{l}\text { Total: } \\
\text { USD } 13.0 \text { mio }\end{array}$ & $\begin{array}{l}\text { Share in imports: } \\
10 \%\end{array}$ & $\begin{array}{l}\text { Total: } \\
\text { USD } 18.2 \text { mio }\end{array}$ & $\begin{array}{c}\text { Share in imports: } \\
3 \%\end{array}$ \\
\hline $\begin{array}{l}\text { Top } 5 \text { products: } \\
\text { - Parts and accessories } \\
\text { - Iron products and steels } \\
\text { - Machineries } \\
\text { - Motor cars } \\
\text { - Piston engines }\end{array}$ & $\begin{array}{l}46 \% \\
53 \% \\
31 \% \\
24 \% \\
49 \%\end{array}$ & $\begin{array}{l}\text { Top } 5 \text { products: } \\
\text { - Petroleum gas } \\
\cdot \text { Coal } \\
\cdot \text { Copper } \\
\cdot \text { Petroleum oil } \\
\text { - Wire }\end{array}$ & $\begin{array}{c}8 \% \\
15 \% \\
17 \% \\
2 \% \\
10 \%\end{array}$ \\
\hline
\end{tabular}

\subsection{The New Trade Pattern and Global Agenda}

In recent years, the economists have been noticing that there are some changes in global trade pattern. The relationship between global growth and global trade is getting weaker. WTO (2017) reported that weak international trade growth in the last few years largely reflects continuing 
weakness in the global economy. The potential of trade to strengthen global growth can remain exist if the movement of goods and supply of services across borders remains strong. However, it is tended that policymakers attempt to address higher restrictions on imports. In this situation, trade cannot help boost growth and may even constitute a drag on the recovery.

WTO (2017) emphasized that the volume of world merchandise trade in historical time has tended to grow about 1.5 times faster than world output. Furthermore, in the 1990s it grew more than twice as fast. However, since the financial crisis, the ratio of trade growth to GDP growth has fallen to around 1.0; and the ratio fell down to 0.6, which is the first time drop below 1.0 since more than 20 years ago. The ratio is expected to partly recover in 2017 , but it remains a cause for concern. The risks of trade to be going to unpredictable direction in the near future will be due to the lack of clarity about government action on monetary, fiscal and trade policies.

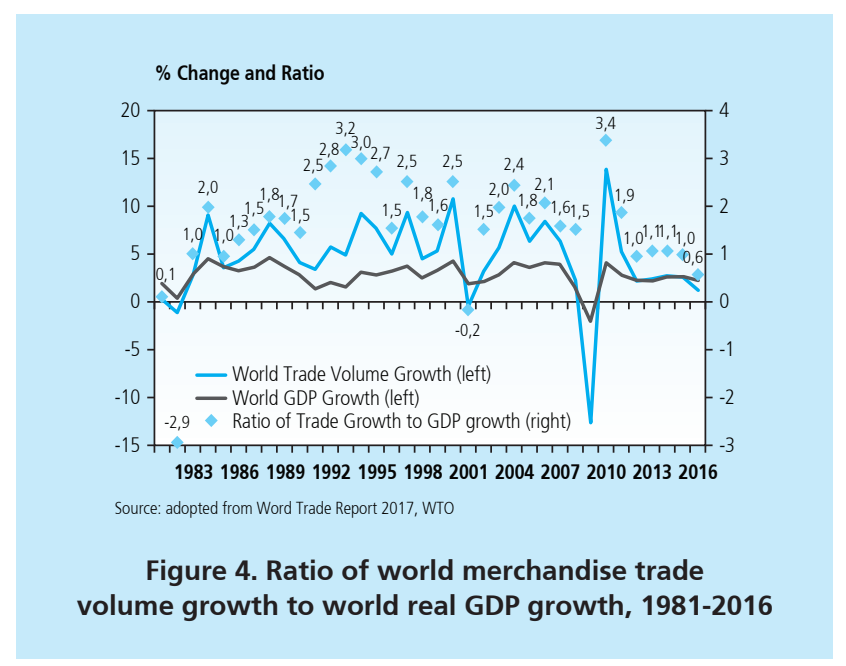

Furthermore, Trump's presidency and his trade agenda has added to higher uncertainties to the global trade. President Donald Trump has been seen as a protectionist; as he cancelled US trade deal in TPP. He also argued that US companies are the victims of the globalization. He pledged to impose tariff on Chinese imports as much as $45 \%$ and on goods imported from Mexico as much as 35\%. Furthermore, in early April 2017, Trump announced the 16 countries that were put in his trade hit list. Those countries are: China, Japan, Germany, Mexico, Ireland, Vietnam, Italy, South Korea, Malaysia, India, Thailand, France, Switzerland and Indonesia, with eight out of 15 of them being in the Asia-Pacific.

Trump's reason to put those countries into the trade hit list was because those countries are the top most import sources creating US trade deficit (Figure 4). The US trade deficit was the largest with China, followed by Japan. Those countries created a trade deficit to the US as 
much as US\$ -365.9 billion and US\$ -72.0 billion in 2016 consecutively. Further to this, Indonesia was ranked at $16^{\text {th }}$ country contributing to US trade deficit. Figure 6 depicts the share of the 16 countries to US imports, which shows that 21.4 percent of US imports was contributed by China. The second and third contribution to US imports were Mexico and Canada, accounted for 13.2 and 12.6 percent consecutively. Furthermore, Japan's and Indonesia's contribution to US imports were only 6.0 percent and 0.9 percent. Surprisingly, Vietnam shared 1.9 percent of US imports and US import growth rate from Vietnam in the last five years reached 20 percent, the highest among the 16 countries.

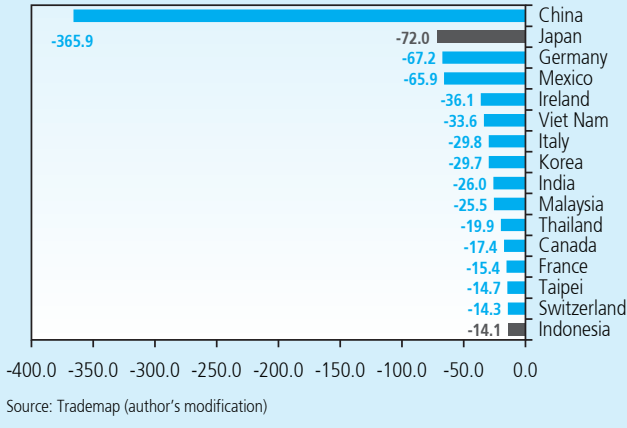

Figure 5. US Trade Deficits with 16 Main Import Sources (USD Billion)

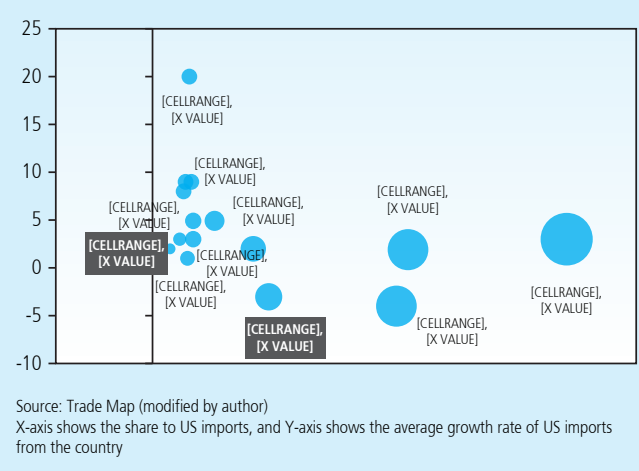

Figure 6. Share to US Imports and Average Growth of US Imports from Each Country

However, a different conclusion emerges from a closer reading of Donald Trump's business interests, which was written in his trade agenda published in the 2016 Annual Report on the Trade Agreements Program by the Office of the United States Trade Representative (USTR). Another look at American trade negotiation history, it is also a possibility that the US will use the large trade deficits to have a further negotiation with its trading partners to open up their markets.

This paper studies the possible impact of new trade agenda into the Indonesian and Japanese economy that may occur through trade channels; and provides some policy recommendation to mitigate such global risk for Indonesian and Japanese economy. There are two scenarios of new trade agenda studied in this paper. Those are: (i) Trump Trade Agenda when implementing 45 and 35 percent tariff to China and Mexico; (ii) Trade Hit List when imposing tariff to the 16 countries in the trade hit list. Impacts of both scenarios are examined in short run and long run. 


\section{THEORY}

There has been an extensive discussion in the literatures on the role of international trade in fostering economic growth. The nexus of trade versus growth is not a new debate. Were (2015) mentions in his paper that Smith (1776) explained trade as a vent for surplus production and a means of widening the market. Adam Smith proposed that trade affects economic growth through two channels. The first channel is that trade can reduce dimension of the internal market. The second channel is by increasing the extension of the market, improving the labour division and increasing productivity. He postulated that division of labour does not depend merely on technological feasibility, it greatly depends on the extent of the market as well and the size of market depends on the availability of stock and the institutional restrictions placed upon both domestic and international trade. Smith's theory of international trade and growth was known as classical theory.

Post classical international trade theory was proposed by Marshall (1890). He acknowledged that economic progress of nations is very much linked to the study of international trade. The expansion of the market created by trade will lead to the increase of global production and originated the increase of internal and external economies, which then resulted in increasing income for the economy. However, the topic has remained a key subject of debate in research and policy discourses, leading to ample theoretical and empirical literature on the link between trade and economic growth.

The renewed interest in the role of trade is largely underpinned by the latest wave of globalization that has been characterized by not just intensive trade integration and trade openness, but has also been associated with technological revolution. Heckscher-OhlinSamuelson theory postulated that trade openness can promote higher levels of output and growth by exploiting comparative advantage and promoting reallocation of resources - which make it more efficient. Daumal and Ozyurt (2010) argued that international trade can foster innovation, the dissemination of technological progress through exposure to new goods and imports of high-tech inputs and efficient production.

Furthermore, WTO (2014) detailed an explanation on how trade affects long-term growth, which is through three channels. First channel is that trade can influence growth by affecting the return to capital accumulation. The second channel is that trade can affect growth through innovation incentives. This includes the effect of trade on market size, competition, and knowledge spillovers. Lastly, trade can have positive effects on economic growth through improving institutional framework. Countries who enter a trade agreement will not only reducing the tariff barriers but also commit to providing a certain institutional framework and trade rules. In summary, WTO (2014) emphasized that trade affects the economic growth due to the existence of accumulated learning-by-doing of specific sectors that leads to an overall productivity. 


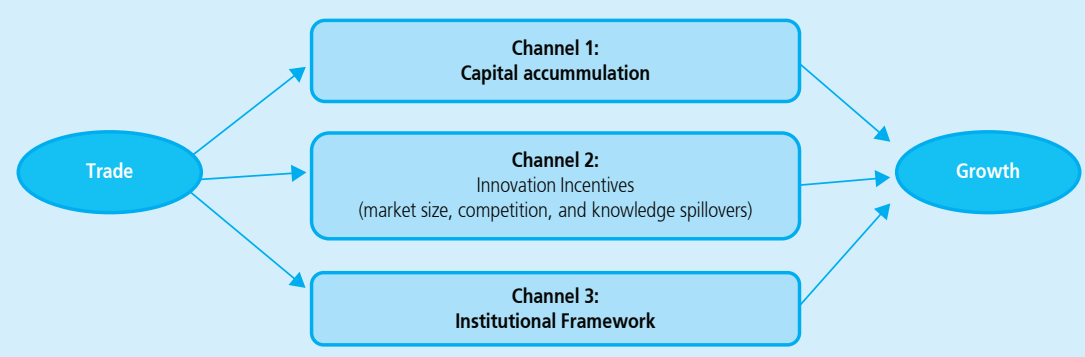

Source: WTO (modified by Author)

Figure 7.

Trade Channels to Growth

Empirically, Were (2015) analyzed the differential impact of trade on economic growth and investment based on cross-country data. The study resulted a positive and significant impact of trade on economic growth. However, it was found that the effect of trade to the economic growth differs at a disaggregated level, where the level of development does matter. Trade significantly and positively affects economic growth in developed and developing countries, but its impact is not significant in Least Developed Countries (LDCs).

This paper goes one step further and explores how international trade can affect output growth differently in the short-run and the long-run. The difference effects will happen In particular due to, international trade can lead to higher growth to the extent that it translates into greater factor accumulation or productivity increases, especially those associated with technology diffusion and knowledge spillovers.

\section{METHODOLOGY}

The paper uses GTAP model, which is essentially a computable general equilibrium model, with sector and country disaggregation available at GTAP version 7. The standard GTAP Model is a multiregion and multisector with a perfect competition and constant returns to scale. Bilateral trade is provided through the Armington assumption. Innovative aspects of this model include ${ }^{2}$ :

- The treatment of private household preferences using the non-homothetic constant difference of elasticity (CDE) functional form.

- The Government demand follows the Cobb-Douglas assumption of constant budget shares across sectors. Elasticity of substitution among composite products in the government's utility function is to be unitary.

2 The GTAP model explanation was obtained from: https://www.gtap.agecon.purdue.edu/models/current.asp 
- The explicit treatment of international trade and transport margins. Bilateral trade is handled via the Armington assumption.

- A global banking sector which intermediates between global savings and consumption.

Endowment factors are disaggregated into Land, Unskilled Labour, Skilled Labour, Capital, and Natural Resources.

The short-run scenario uses the existing GTAP closures, where the capital stock is determined exogenously, because it is a period of time before new investment adds to the total availability of capital. In this regard, changes of output in capital goods sector (qo( "Capital",r) is set to zero, satisfying the short run condition that capital stock $(\mathrm{kb}(\mathrm{r}))$ is not changed. Furthermore, the expected global rate of return is allowed to adjust to ensure the regional composition of global investment remain unchanged. In this condition, parameter of RORDELTA ${ }^{3}$ is set to zero.

The long-run scenario in this paper is treated by using the methodology somewhat between longrun closures of Francois et.al (1996) and of Walmsley (1998). The characteristics of long-run scenario is depicted by endogenizing capital stock. In this context, the output of capital goods sector (qo("Capital",r)) is endogenous; thus the investment levels relative to endowment stock (EXPAND("Capital",r) is exogenous and set to zero (Francois et.al, 1996), with the following relationship:

$$
\operatorname{EXPAND}(i, r)=q c g d s(r)-q o(i, r)
$$

When EXPAND("Capital",r) is zero, then output of capital goods will equate the change of investment level (qcgds(r), and therefore capital stock $(k b(r))$ will also be changed.

However, the setting of long run closure in this paper is also referring to Walmsley (1998), where the trade balance (DTBAL $(r))$ is endogenous to ensure the transmission of trade policy in the long-run to the adjustment of regional current account balance ${ }^{4}$. Endogenizing the trade balance will result in the condition where the accumulation effect of capital reflects the changes in capital stocks necessary to equate rate of return accrose the time. Therefore:

$$
\operatorname{rorc}(r)=\operatorname{rore}(r)
$$

Aside from this, RORDELTA is set to 1, representing the situation where global saving across investment is allocated in such away the expected rates of return will equate across

3 RORDELTA is a binary coefficient which determines the mechanism of allocating investment funds across regions. When RORDELTA = 1 , investment funds are allocated across regions to equate the change in the expected rates of return (i.e., rore(r)). When RORDELTA $=0$, investment funds are allocated across regions to maintain the existing composition of capital stocks.

4 Francois et.al (1996) fixes the trade balance; therefore the percentage change in each region current and expected rates of return do not equate across regions in the long-run. 
regions (composition of global net investment is changed, but the expected global rate of return does not change).

$$
\text { rore }(r)=\operatorname{rorg}
$$

\section{RESULT AND ANALYSIS}

The simulation is divided into two groups. First is the scenario when Trump implements import tariff to China and Mexico, as he promised during his election campaign. At this stage, China and Mexico do not undertake any trade retaliation. Second is the scenario when Trump only implement import tariff to countries in the hit list. These countries get 15 percent tariff to all products they export to US market. Both scenarios are examined within short-run and longrun. The short-run scenario uses the standard GTAP closure, where the long-run scenarios use the methodology as explained in the previous section above. The framework of simulation scenarios is depicted in Figure 8.

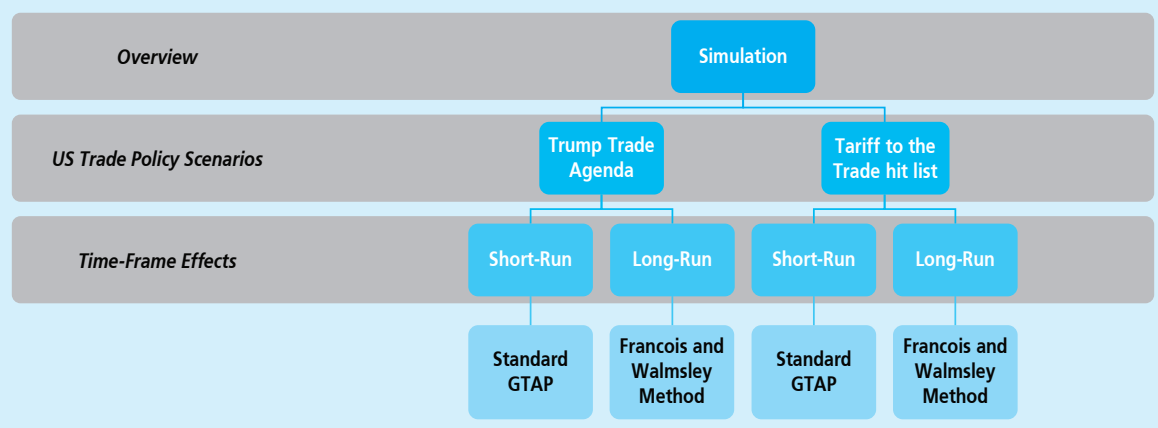

Figure 8.

Simulation Scenarios 


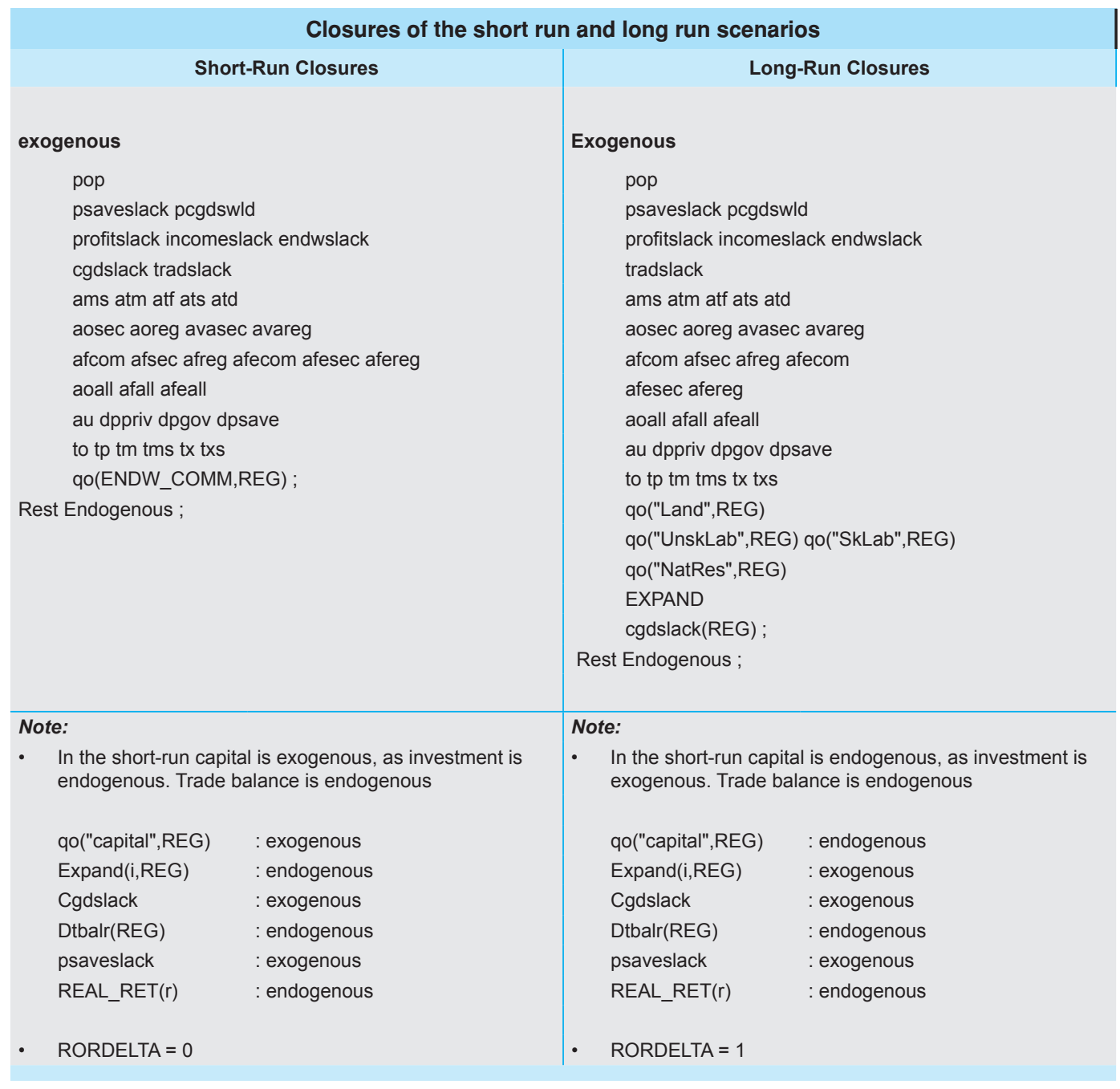

\subsection{Trump Trade Agenda}

\section{(45 percent import tariff for China and 35 percent import tariff for Mexico)}

The simulation results show that the implementation of Trump's trade agenda, in which 45 percent import tariff applied to Chinese products and 35 percent import tariff applied to Mexican products, will not significantly effect global economy nor Indonesian and Japanese economy in the short run. Countries that will be worse-off in the short run from the trade agenda is USA, China and Mexico. Among the three economies, Mexico will get suffer most from this agenda. 


\begin{tabular}{|c|c|c|}
\hline \multicolumn{3}{|c|}{$\begin{array}{l}\text { Table } 3 . \\
\text { Effects of Trump Trade Agenda to Some Economies }\end{array}$} \\
\hline & Short Run & Long Run \\
\hline \multicolumn{3}{|c|}{ Change in GDP (\%) } \\
\hline 1 Indonesia & 0.0 & 0.3 \\
\hline 2 EU_25 & 0.0 & 0.1 \\
\hline 3 Japan & 0.0 & 0.1 \\
\hline 4 USA & -0.4 & -0.7 \\
\hline 5 China & -0.5 & -2.7 \\
\hline 6 Mexico & -0.8 & -12.1 \\
\hline 7 RestofASEAN & 0.1 & 0.7 \\
\hline 8 RestofASIA & 0.0 & 0.2 \\
\hline 9 RestofWorld & 0.0 & 0.3 \\
\hline TOTAL WORLD & 0.0 & -0.2 \\
\hline \multicolumn{3}{|c|}{ Change in Welfare (EV) } \\
\hline Total Welfare (World) & -54000.3 & -133807.1 \\
\hline Source: Author's simulation & & \\
\hline
\end{tabular}

The reason is that Mexico relies much on the US market for its exports. Around 81 percent of its exports are directed to US. It shows that high dependency of Mexico on the US market has made it very vulnerable to any shock from the US economy, particularly when there is a trade shock. On the other hand, the impact of Trump Agenda is less to China than to Mexico, because it is only 18.4 percent of Chinese exports directed to US. This is in line with the empirical findings of Shivarov (2014) that countries with higher export diversification - either diversification in main trading partners or products --will have a better economic resilience. Furthermore, UNDP (2011) also emphasized that economic openness can explain the situation in which an economy may be vulnerable to external economic shocks (as decreasing in exports results in losses in export revenues and growth slowdowns). However, the scale of impact depends largely on the degree of concentration of a country's export portfolio; higher degrees of export concentration are strongly correlated with greater volatility in export earnings and economic growth rates.

\begin{tabular}{l|r}
\multicolumn{2}{c}{ Table 4. } \\
\multicolumn{3}{c}{ Market Concentration Index } \\
Country & \multicolumn{1}{c}{ Market Concentration Index (2015) } \\
China & 0.07 \\
Mexico & \\
Indonesia & 0.55 \\
Japan & \\
\end{tabular}


To Japan and Indonesia, even though US is one of their main export destination, but it is only 11.2 percent of Indonesian export directed to the US and 20.2 percent of Japan export directed to the US.

Furthermore, it is important to note that the agenda will not be good to the global economy in the long run, as the world GDP will be declining and the total welfare loss of the global economy will be higher. The global supply of capital goods for net investment will be declining, and this will be the main reason that affects long-term growth of global economy. The volume of world trade will also be worsening in the long run, creating a shrinking of market size, and the end will result in a lower growth in the long run.

\begin{tabular}{|c|c|c|}
\hline \multicolumn{3}{|c|}{$\begin{array}{l}\text { Table } 5 . \\
\text { Effect of Trump Agenda to the Global Economy }\end{array}$} \\
\hline Description & Short Run & Long Run \\
\hline - Global supply of capital goods for NET investment & -0.6 & -1.0 \\
\hline - Volume of world trade & -1.1 & -1.3 \\
\hline - Global net rate of return on capital stock & -0.6 & 0.0 \\
\hline - Value of world trade & -1.2 & -1.4 \\
\hline - Demand in the omitted market--global demand for savings & -0.6 & -1.0 \\
\hline - Supply in omitted market--global supply of capital goods & -0.6 & -1.0 \\
\hline
\end{tabular}

Trump's trade agenda will definitely hurt the economy of China, Mexico, and USA in the long-run. Again, Mexico will suffer most from the trade agenda in the long run. It can be seen that the effect is worsened in the long run, as the decrease of capital accumulation in these three countries will dampen the economies to maintain the long-run growth. This result is in line with the findings from Kawasaki (2017), showing that Mexico, China, and US will suffer by this trade agenda. Kawasaki (2017) also emphasizes that US chemical and auto industries will largely decrease when China retaliates; and US textile, auto, and chemical industries will significantly decrease when Mexico retaliates.

Innovation through the market size is decreasing in the long-run due to reduction of Chinese and Mexican markets in the US. Given that US market was mainly shared by Chinese and Mexican products, reduction of US imports from these two countries will hamper the term of trade of these countries. Furthermore, the US restriction on Chinese imports will reduce the US exports both in short and long run, as some of the industrial outputs will be redirected to domestic markets. In this regard, the US market size in the global market will be shrinking, even though its term of trade is still increasing. The reduction of market size will result in decreasing of innovation incentives, and will further reduce the economic growth in the long-run. However, the trump agenda can reduce US trade deficit in the long run, but not in the short run. 


\begin{tabular}{|c|c|c|}
\hline \multicolumn{3}{|c|}{$\begin{array}{l}\text { Table } 6 . \\
\text { Change in Trade Balance of Some Countries in Short Run and Long Run }\end{array}$} \\
\hline Country & Short Run & Long Run \\
\hline Indonesia & 298.2 & 49.0 \\
\hline Japan & 3676.3 & 438.0 \\
\hline USA & -2605.5 & 2626.8 \\
\hline China & -16538.4 & -5435.5 \\
\hline Mexico & -4286.5 & 586.8 \\
\hline
\end{tabular}

However, Trump's trade agenda does not seem to create a negative effect to the Indonesian and Japanese economy, particularly in the long run; if both countries are able to utilize the market opportunities in particular in the US Market. There are possibilities of trade diversion and trade creation effects for Indonesia and Japan. In the short run, Indonesia and Japan can get a trade diversion effect, as import restriction applied to China and Mexico can provide market opportunities in the US because US domestic industries are not yet ready to fulfill all its domestic demand. Furthermore, since the US market opportunities are big enough, then Indonesia and Japan may have some room to get trade creation effects. This will result in an increase of Indonesian and Japanese trade surplus in the short run (Table 6).

In the long run, the US industries can adjust to the situation and able to adapt to the domestic market opportunities, leaving the smaller trade surplus to Indonesia and Japan. In the long run, US can have a smaller trade deficit by reducing the amount of imports for its domestic demand. For Indonesia and Japan, the market opportunities created from trade diversion and trade creation effects can generate a capital accumulation in the long run. Indonesian and Japan trade competitiveness -- depicted by terms of trade -- will also increase, providing a better room for these countries to export more and providing an opportunities to innovate more. These capital accumulation and increase of market opportunities would be the reasons of the long run effects to Japan and Indonesia.

\begin{tabular}{|c|c|c|c|c|}
\hline \multicolumn{5}{|c|}{$\begin{array}{l}\text { Table } 7 . \\
\text { Percentage Change of Capital Stock in Each Country in the Long Run }\end{array}$} \\
\hline \multirow{2}{*}{ Countries } & \multicolumn{2}{|c|}{ Capital Stocks } & \multicolumn{2}{|c|}{ Terms of Trade } \\
\hline & Short Run & Long Run & Short Run & Long Run \\
\hline 1 Indonesia & 0 & 0.6 & 0.4 & 0.3 \\
\hline 3 Japan & 0 & 0.3 & 0.7 & 0.8 \\
\hline 4 USA & 0 & -1.1 & 1.8 & 1.7 \\
\hline 5 China & 0 & -4.8 & -3.3 & -3.1 \\
\hline 6 Mexico & 0 & -20.3 & -13.7 & -12.7 \\
\hline
\end{tabular}




\subsection{Trade Hit List}

\section{(15 percent import tariff for countries in the trade hit list)}

Simulation of Trade Hit List scenario is undertaken by imposing 15 percent tariff of US imports from the 16 countries in the Trade Hit List. The simulation is conducted to assess the short run and long run effects, in particular to Indonesia and Japan.

The simulation results show that the implementation of 15 percent tariff to the trade hit list countries -including Japan and Indonesia -will not give any significant effect to the global GDP in the short run. However, the change of equivalent variant - which is a welfare indicator - is negative, meaning that there are still a welfare loss even though the global GDP does not change much in the short run.

The trade hit list agenda will disadvantage the global economy and all countries in the trade hit list for the long run. The long run GDP will decrease. Furthermore, the global welfare loss in the long run is higher than that of the short run. Another interesting result is that global trade will be shrinking and global net investment will also decrease in both short run and long run. It is important to highlight that all global macro indicators are worsened in the long run. A decrease of net investment in the short run may cause the decrease income. Furthermore, it will result in a decreased demand of savings, which means reducing the capability to increase the capital stock in the long run. When the capital stock is declining, the long run growth will also reduce.

\begin{tabular}{|c|c|c|}
\hline \multicolumn{3}{|c|}{$\begin{array}{l}\text { Table } 8 . \\
\text { Effects of Trade Hit List Agenda to the Global Economy in Short Run and Long Run }\end{array}$} \\
\hline Description & Short Run & Long Run \\
\hline - Change in World GDP & 0.0 & -0.5 \\
\hline - Global supply of capital goods for NET investment & -0.9 & -1.4 \\
\hline - Volume of world trade & -2.2 & -2.7 \\
\hline - Global net rate of return on capital stock & -0.4 & 0.4 \\
\hline - Value of world trade & -2.8 & -3.4 \\
\hline - Demand in the omitted market--global demand for savings & -0.9 & -1.4 \\
\hline - Supply in omitted market--global supply of capital goods & -0.9 & -1.4 \\
\hline - Equivalent variation for the world (change) & -26537.1 & -171044.7 \\
\hline
\end{tabular}

The negative impact of the trade hit list agenda will be experienced by Indonesia and Japan in the long run, as well as most of economies in the trade hit list. However, Indonesia will get a worse effect than Japan will. 


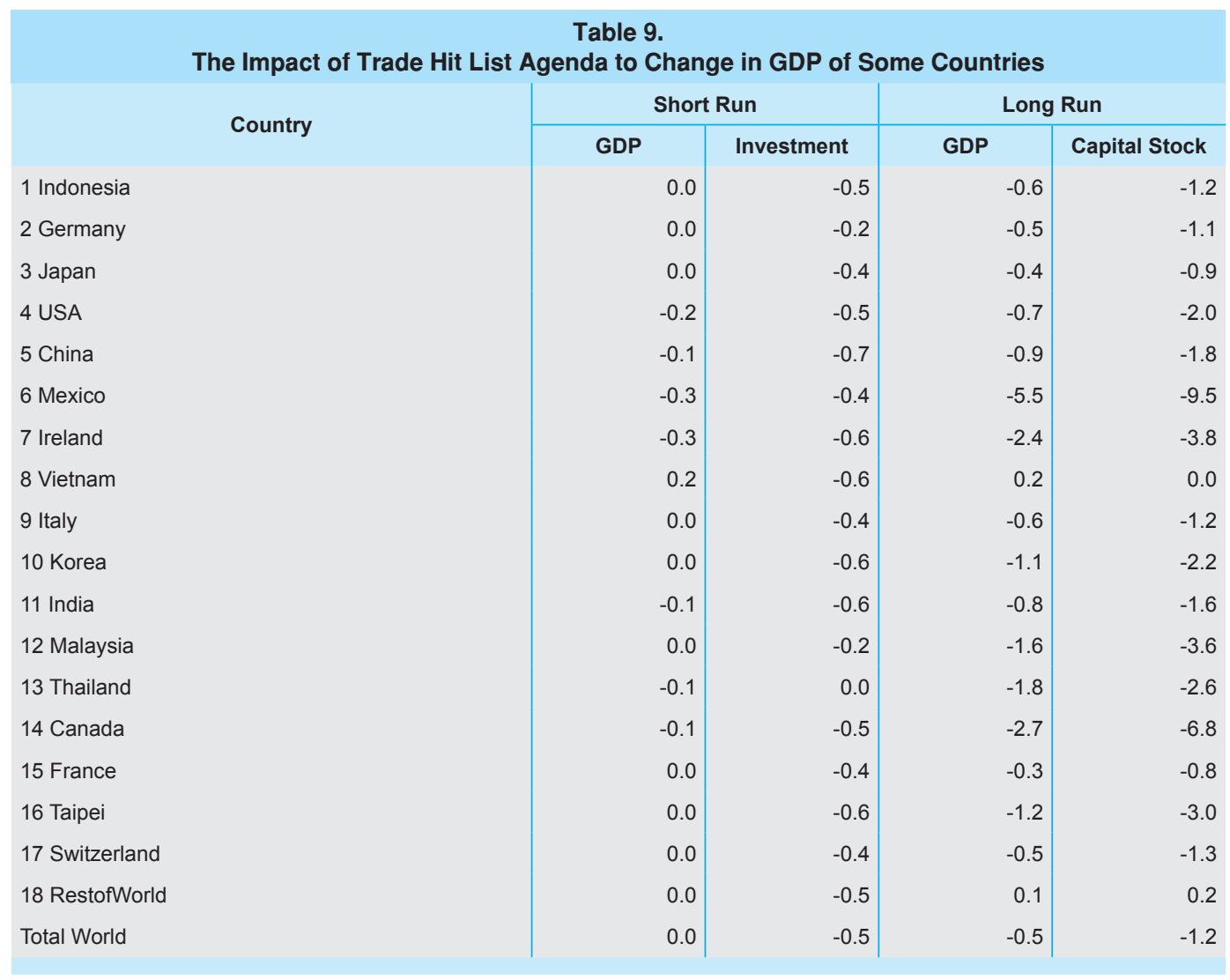

When Indonesia and Japan get trade restriction from the US, its export to US will decline. This will be transmitted to the Indonesian and Japan economy through trade channel, affecting private demand to go down. When private demand goes down, it will affect imports to decline and the industrial outputs will also be affected.

To Indonesia, the implementation of trade hit list agenda will impact only some sectors in the short run, such as: Processed Food, Light and Heavy Manufacturing, Utilliy and Transportation. However, all sectors will hurt from this agenda in the long run. The output of capital goods industry will also decline, both in the short run and long run. 


\begin{tabular}{|c|c|c|c|c|c|c|c|c|}
\hline \multicolumn{9}{|c|}{$\begin{array}{c}\text { Table } 10 . \\
\text { Economic Performance of Indonesia by Sectors After the Implementation of Trade Hit List Agenda }\end{array}$} \\
\hline & \multicolumn{2}{|c|}{ Private Demand } & \multicolumn{2}{|c|}{ Exports } & \multicolumn{2}{|c|}{ Import } & \multicolumn{2}{|c|}{ Industrial Output } \\
\hline & Short Run & Long Run & Short Run & Long Run & Short Run & Long Run & Short Run & Long Run \\
\hline 1 GrainsCrops & -0.1 & -0.3 & -2.3 & -1.2 & -1.5 & -2.6 & 0 & -0.1 \\
\hline 2 MeatLstk & -0.1 & -0.5 & 3.5 & 4.2 & -4 & -5 & 0.3 & -0.1 \\
\hline 3 Extraction & -0.2 & -0.6 & 2.3 & 1.3 & -2.5 & -3.1 & 0.6 & -0.1 \\
\hline 4 ProcFood & -0.1 & -0.5 & -0.8 & -0.9 & -1.5 & -2.1 & -0.1 & -0.4 \\
\hline 5 TextWapp & -0.1 & -0.6 & 4.7 & 3.7 & 2.2 & 1.5 & 2.7 & 1.9 \\
\hline 6 LightMnfc & -0.1 & -0.7 & -0.9 & -1.8 & -0.8 & -1.4 & -0.4 & -1.1 \\
\hline 7 HeavyMnfc & -0.2 & -0.7 & -2.7 & -3.1 & -0.9 & -1.6 & -1 & -1.5 \\
\hline 8 Util_Cons & -0.1 & -0.6 & 2.2 & 1.6 & -2 & -2.5 & -0.4 & -1 \\
\hline 9 TransComm & -0.1 & -0.7 & -0.8 & -1.4 & -1.3 & -1.8 & -0.1 & -0.7 \\
\hline 10 OthServices & -0.1 & -0.8 & -2.2 & -3.7 & -1.9 & -2.1 & 0 & -0.7 \\
\hline 11 Capital Goods & & & & & & & -0.5 & -1.2 \\
\hline
\end{tabular}

To Japan, the implementation of trade hit list agenda will impact only some sectors in both short run and long run. Those sectors are: Processed Food, Light and Heavy Manufacturing, as well as services. The output of capital goods industry will also decline, both in the short run and long run, but the decline is smaller than that of Indonesia. The smaller decline of capital goods output in Japan than in Indonesia has resulted smaller decline of capital stock. This condition has made the impact of trade hit list to Japan economy is smaller than that of Indonesia in the long run.

However, the simulation results show that Vietnam will not be worse-off from this trade agenda, both in the short run and in the long run. The explanation is that the power of trade diversion effects from the Trade List agenda, due to Vietnam's export comparative advantage in electrical, textiles/apparels, and footwear sectors.

\begin{tabular}{|c|c|c|c|c|c|c|c|c|}
\hline \multicolumn{9}{|c|}{$\begin{array}{l}\text { Table } 10 . \\
\text { Economic Performance of Japan by Sectors After the Implementation of Trade Hit List Agenda }\end{array}$} \\
\hline & \multicolumn{2}{|c|}{ Private Demand } & \multicolumn{2}{|c|}{ Exports } & \multicolumn{2}{|c|}{ Import } & \multicolumn{2}{|c|}{ Industrial Output } \\
\hline & Short Run & Long Run & Short Run & Long Run & Short Run & Long Run & Short Run & Long Run \\
\hline 1 GrainsCrops & 0.0 & 0.0 & 2.0 & 0.8 & -2.2 & -2.2 & 0.6 & 0.4 \\
\hline 2 MeatLstk & -0.5 & -0.7 & 4.6 & 2.9 & -2.6 & -2.5 & 0.9 & 0.5 \\
\hline 3 Extraction & -1.1 & -1.0 & -2.0 & -5.0 & -0.3 & -0.7 & 1.1 & 0.6 \\
\hline 4 ProcFood & -0.4 & -0.6 & 0.4 & -0.2 & -2.3 & -2.5 & 0.0 & -0.3 \\
\hline 5 TextWapp & -0.3 & -0.6 & 2.6 & 2.5 & -0.8 & -1.2 & 0.7 & 0.5 \\
\hline 6 LightMnfc & -0.4 & -0.7 & -2.7 & -3.1 & -4.2 & -4.7 & -0.4 & -0.8 \\
\hline 7 HeavyMnfc & -0.5 & -0.7 & -0.3 & -1.1 & -3.5 & -4.0 & 0.4 & -0.2 \\
\hline 8 Util_Cons & -0.2 & -0.4 & 5.1 & 5.0 & -3.8 & -4.4 & -0.2 & -0.7 \\
\hline 9 TransComm & -0.2 & -0.4 & 0.6 & 0.2 & -2.8 & -3.2 & 0.0 & -0.3 \\
\hline 10 OthServices & -0.1 & -0.5 & -3.4 & -4.0 & -4.3 & -4.6 & 0.0 & -0.4 \\
\hline 11 Capital Goods & & & & & & & -0.4 & -0.9 \\
\hline
\end{tabular}


As the new trade agenda will cause some downside risks to the Indonesian and Japanese economies, the governments would better to take some policy actions in order to mitigate the long-term risks ${ }^{5}$ to the economies. This paper offers some policy options and simulate the long-run effects of implementation of each policy option.

To Indonesia, some policy options could be: (i) increasing investment to Indonesia through a better investment climate. In the model, this policy option is represented by providing a decrease of risk premia ${ }^{6}$ in Indonesia, as it can represent the investor valuation on how the improvement in investment climate undertaken by the government of Indonesia can influence their investment decision; (ii) Improving the investment climate and improving productivity of unskilled labour. For this policy option, the simulation is undertaken by providing two shocks, i.e. a reduced risk premia and an increase productivity (technological change) in primary input of unskilled labour?

\section{CONCLUSION}

The new trade agenda - represented by Trade Trump Agenda and Trade Hit List Agenda -- will create disadvantages to global economy in general, as well as to Indonesian and Japanese economy. The new trade agenda will be transmitted to Indonesian and Japanese economy through trade channels.

When Trump Trade Agenda is implemented to China and Mexico, there will be no significant impact to both Indonesian and Japanese economy in the short run. Indonesia and Japan will get trade creation and trade diversion effect from this agenda. For Indonesia and Japan, the market opportunities created from trade diversion and trade creation effects can generate a capital accumulation in the long run. These capital accumulation and increase of market opportunities would be the reasons of the long run effects to Japan and Indonesian economies.

If Trade Hit List Agenda is implemented by the US; Indonesia and Japan will get disadvantages, particularly in the long run. When Indonesia and Japan get trade restriction from the US, its export to US will decline. This will be transmitted to the Indonesian and Japan economy through trade channel, affecting private demand to go down. When private demand goes down, it will affect imports to decline and the industrial outputs will negatively be affected.

5 All simulations in the policy options of both Indonesia and Japan are using the long-run closures, where RORDELTA=1 and capital stock (qo("capital",REG) is endogenous). In this context, cgdslack is remained exogenous.

6 A change in the risk premia is represented by implementing a shock on cgdslack (Malcolm, 1998), following the equation of rore $(r)=$ rorg + cgdslack $(r)$. This equation states that the percentage change in the rate of return on investment in region $r$ is equal to the the percentage change in the global rate of return plus a risk premia.

7 The technical change on primary input of unskilled labour is implemented by imposing a shock on technical change variable in traded commodities in Indonesia, which is: afeall("SkLab",TRAD_COMM,"Indonesia") 
In summary, any new trade restriction agenda will affect the global economy, particularly in the long run. The welfare loss will also happen in the short run and long run, but the loss will be higher in the long run.

Looking at the long run effect of this new trade agenda, Indonesia and Japan should focus on the policy to mitigate the impact in the long run. It is suggested that Japan and Indonesia could focus on the following policies:

a. Japan: technological innovation can help Japan to increase its productivity and mitigate the global risks to its economy in the long run. Japan has to be able to implement its government plan on Industry 4.0 to ensure the innovation process in place. Furthermore, considering the ageing society in Japan, an increase in labour supply can be managed by encouraging women to participate into the labour force and increase the pension age. Encouraging family to have more children will also benefit to ensure the labour supply in the future, whilst at the same time the government should provide more facilities for child care and elderly-care; therefore women can have more hours for working.

b. Indonesia: the readiness of technological innovation in Indonesia is not as advanced as what Japan has planned. However, it does not mean that Indonesia cannot mitigate the global risks in the long term. Indonesia can focus on attracting more investment to induce capital accumulation in the long term, as the simulation results show that capital accumulation can support the long term growth and mitigate the global risks. Furthermore, increasing total factor productivity can be another focus of Indonesia, such as: intensifying infrastructure development, enhancing regulatory efficiencies in particular for businesses, as well as improving labour market efficiency. 


\section{REFERENCES}

Andersen, L. and R. B. (2008). The Link between Openness and Long-Run Economic Growth. Journal of International Commerce and Economics, US International Trade Commission.

Francois, J. et. a. (1996). Liberalization and Capital Accumulation in GTAP Model, GTAP Technical Paper.

Kawasaki, K. (2017). Emergent Uncertainty in Regional Integration - Economic Impacts of Alternative RTA Scenarios (GRIPS Discussion Paper). Japan.

Levchenko. (2009). The Collapse of International Trade during the 2008-2009 Crisis: In Search of the Smoking Gun. IMF Seminar Paper.

Mayer, J. (2010). Global Rebalancing: Effects on Trade Flows and Employment (UN Discussion Paper No. 200).

Scherrer, C. (2017). Trump's Trade Policy Agenda: More Liberalization. Retrieved from http:// www.globalresearch.ca/trumps-trade-policy-agenda-moreliberalization/\%0A5595903

Shivarov, A. (2014). Diversity in Bulgarian Foreign Trade. Journal of Ikonomik. Retrieved from http://www.su-varna.org/izdanij/2014/lkonomik-2014/Pages 63-71.pdf

The European Financial Crisis. (n.d.). Analysis and a Novel Intervention. Harvard University.

UNDP. (2011). Export Dependence and Export Concentration, in Towards Human Resilience: Sustaining MDG Progress in an Age of Economic Uncertainty.

Walmsley, T. (1998). Long Run Simulations with GTAP: Illustrative Results from APEC Trade Liberalisation (GTAP Technical Paper).

Were, M. (2015). Differential effects of trade on economic growth and investment: A crosscountry empirical investigation. Journal of African Trade, 2, 1-2.

WTO. (2017). Trade Statistics and Outlook. Retrieved from http://www.matrade.gov.my/en/ for-foreign-buyers/industry-capabilities/trade-statistics 
202 Buletin Ekonomi Moneter dan Perbankan, Volume 20, Nomor 2, Oktober 2017

Halaman ini sengaja dikosongkan 